IRA-International Journal of Applied

Sciences

ISSN 2455-4499; Vol.04, Issue 03 (2016)

Institute of Research Advances

Pg. no. 530-540

http://research-advances.org/index.php/IRAJAS

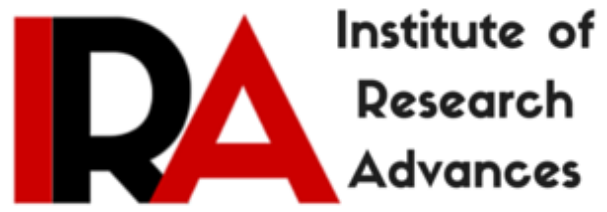

\title{
Ambient and Elevated Ozone (O3) impacts on Potato Genotypes (Solanum tuberosum.L) over a high altitude Western Ghats location in Southern India
}

\author{
V.S. Suganthy ${ }^{1} \&$ C. Udayasoorian ${ }^{2}$ \\ ${ }^{1}$ ISRO - Climate Change Observatory, Horticultural Research Station, Tamil Nadu \\ Agricultural University, Ooty, 643001, India. \\ ${ }^{2}$ Department of Soil Science \& Agricultural Chemistry, Agricultural College \& Research \\ Institute, Tamil Nadu Agricultural University, Killikulam, 628 252, India.
}

Type of Review: Peer Reviewed.

DOI: http://dx.doi.org/10.21013/jas.v4.n3.p16

\section{How to cite this paper:}

Suganthy, V., \& Udayasoorian, C. (2016). Ambient and Elevated Ozone (O3) impacts on Potato Genotypes (Solanum tuberosum.L) over a high altitude Western Ghats location in Southern India. IRA-International Journal of Applied Sciences (ISSN 2455-4499), 4(3), 530-540. doi:http://dx.doi.org/10.21013/jas.v4.n3.p16

(C) Institute of Research Advances

\section{(cc) BY-NC}

This work is licensed under a Creative Commons Attribution-Non Commercial 4.0 International License subject to proper citation to the publication source of the work.

Disclaimer: The scholarly papers as reviewed and published by the Institute of Research Advances (IRA) are the views and opinions of their respective authors and are not the views or opinions of the IRA. The IRA disclaims of any harm or loss caused due to the published content to any party. 


\begin{abstract}
Globally, next to $\mathrm{CO}_{2}$ and Methane, raising levels of tropospheric ozone $\left(\mathrm{O}_{3}\right)$, acts as a secondary pollutant and green house gas which is a silent threat as well as one of the biggest challenges for the decrease in agricultural production. The diurnal and seasonal variation characteristics of ambient ozone $\left(\mathrm{O}_{3}\right)$ and its precursor NOx was investigated by their continuous measurements at ISROClimate Change Observatory situated in a high altitude Western Ghats location of Ooty. The impact of ambient $\mathrm{O}_{3}$ on the growth and yield characteristics of various potato genotypes were assessed by the calculated higher ozone exposure indices AOT40 and SUM60 than critical levels by showing "latent injury" in the form of yield reduction (4.56-25.5\%) in potato genotypes. The impact of three elevated $\mathrm{O}_{3}$ levels $\left(100,150\right.$ and $200 \mathrm{ppb}$ for $\left.4 \mathrm{hd}^{-1}\right)$ on ten potato genotypes was done by fumigation under controlled open-top chamber during its critical stage namely the tuber initiation stage resulted that Kufri Surya proved to be moderately resistant by recording the highest yield.
\end{abstract}

\title{
KEYWORDS
}

Tropospheric Ozone, Secondary Air Pollutant, Ozone exposure indices, Elevated ozone, Potato yield

\section{INTRODUCTION}

Ozone $\left(\mathrm{O}_{3}\right)$ is present throughout the atmosphere but can be either negative or positive depending on where it is found whether in troposphere or stratosphere, respectively (Colls 1997). Tropospheric ozone is a powerful oxidant by causing damage to mucus and respiratory tissues in animals and also tissues in plants, above concentrations of about $100 \mathrm{ppb}$ which makes ozone a potent respiratory hazard and pollutant near ground level (Bell et al. 2005). Low level ozone (or tropospheric ozone) is not only a secondary air pollutant but also a green house gas, next to $\mathrm{CO}_{2}$ and Methane affects the growth and yield of agricultural and horticultural crops in most parts of the world (IPCC 2001). Low level or surface ozone is not emitted directly by car engines or industrial operations but formed by the reaction of sunlight on air containing hydrocarbons and nitrogen oxides that react to form ozone directly at the pollution site or many kilometers downwind (Hagerman et al. 1997).

There is evidence of significant reduction in agricultural yields because of increased ground level ozone and pollution which interferes with photosynthesis and stunts overall growth of plant species (NASA 2003). Inter-Governmental Panel on Climate Change (IPCC) and World Meteorological Organization (WMO) assessment reports had predicted $\mathrm{O}_{3}$ concentration raised by $1-2 \%$ in the industrialized countries. Due to rapid economic development during the past decades, surface $\mathrm{O}_{3}$ increased at an annual rate of $0.5-2.0 \%$ (Vingarzan 2004) and has now reached a global mean of approximately $50 \mathrm{ppb}$ for $8 \mathrm{~h}$ summer seasonal average (Anonymous 2008).

Increasing levels of $\mathrm{O}_{3}$ are an additional and extremely important factor in reducing crop yields by 5$35 \%$ of agriculturally important locations across South Asia (Emberson and Büker 2008). Projections of future global $\mathrm{O}_{3}$ trends show that $\mathrm{O}_{3}$ concentration in the ambient air will increase rapidly over the next 20 to 30 years with South Asia projected to experience the highest increase in surface $\mathrm{O}_{3}$ (average annual increases of $7.2 \mathrm{ppb}$ occurring by 2030) (Dentener et al. 2005). Studies showed that the impact of $\mathrm{O}_{3}$ increased with developmental stages, and the largest detrimental effect during critical stage of crop (Feng et al. 2010). Moreover, elevated $\mathrm{O}_{3}$ tends to decrease stomatal functioning and photosynthetic rate leading to concurrent reduction of crop yield (Saurer et al. 1991).

The present work was carried out to assess the impact of ambient and elevated levels of ozone $\left(\mathrm{O}_{3}\right)$ on the growth and yield characteristics of potato (Solanum tuberosum L.) genotypes which is a is moderately sensitive to $\mathrm{O}_{3}$ and it is an important food crop as well as stock feed and in the order of importance of food production it ranks $6^{\text {th }}$ in the developing countries, $4^{\text {th }}$ in developed countries, $4^{\text {th }}$ in the world and $3^{\text {rd }}$ in India $(\mathrm{FAO}, 2000)$. In India, about $8 \%$ area under potato cultivation lies in the Nilgiris hills, it occupies approximately $33-49 \%$ of total vegetable cultivated area every year. The average productivity of spring season (Jan-April) potato is about16.6 $\mathrm{t} \mathrm{ha}^{-1}$, whereas the average 
productivity of summer (April-July) grown potato is about $22.5 \mathrm{t} \mathrm{ha}^{-1}$ with $5.9 \mathrm{t} \mathrm{ha}^{-1}$ of difference in productivity due to various reasons.

\section{MATERIALS AND METHODS}

\section{(i) IMPACT OF AMBIENT OF OZONE (O3) ON POTATO GENOTYPES}

A continuous measurement of ozone was made at ISRO Climate Change Observatory, Tamil Nadu Agricultural University, Woodhouse farm, Ooty from January 2011 to April 2013 using ozone analyzer model $49 \mathrm{i}$, which is based on UV absorption photometry, resting upon absorption of radiation of wavelength $254 \mathrm{~nm}$ by ozone in the analyzed sample. The impact of ambient ozone on different genotypes of potato were analyzed by the calculated AOT40 and SUM60 values by the method of cumulative ozone exposure-plant effect during its growing seasons.

\section{Exposure Indices}

AOT40 is calculated as the sum of differences between the hourly mean concentrations $\left(\mathrm{O}_{3}\right)$ and 40 ppb for hours when $\mathrm{O}_{3}>40 \mathrm{ppb}$, for each daylight hour with global radiation $\geq 50 \mathrm{Wm}^{-2}$ over a 3 months period:

$\mathrm{n}$

$\mathrm{AOT} 40=\sum\left(\left[\mathrm{O}_{3}\right]-40\right) \mathrm{i}$ for $\left[\mathrm{O}_{3}\right]>40 \mathrm{ppb}$.

$\mathrm{i}=1$

where $\mathrm{n}$ is the number of hours $(i)$ that the threshold of $40 \mathrm{ppb}$ is exceeded.

SUM60 is defined as the sum, over a 3 months period, of the hourly $\mathrm{O}_{3}$ concentration for daylight hours $(0700-2100 \mathrm{~h})$ when the concentration $\left(\mathrm{O}_{3}\right)$ is at or above $60 \mathrm{ppbh}(0.06 \mathrm{ppmh})$.

$\mathrm{n}$

$\operatorname{SUM} 60(\mathrm{ppmh})=\sum\left(\mathrm{C}_{\mathrm{O} 3}\right) \mathrm{i} \quad$ for $\left[\mathrm{C}_{\mathrm{O} 3}\right] \geq 60$ in 3 months

$$
\mathrm{i}=1
$$

where $\mathrm{n}$ is the number of hours $(i)$ that the threshold is exceeded (Karenlampi and Skarby 1996).

Simultaneously,the field experiments were conducted by the selected four genotypes of potato viz., Kufri Swarna, Kufri Jyothi, Kufri Giridhari and Kufri Himalini for comparing the yield performances during the two growing seasons namely spring and summer of 2011-2013. For spring and summer cropping, planting was done on $2^{\text {nd }}$ January and $1^{\text {st }}$ April of the years 2011, 2012 and 2013 in a randomized block design with three replications. Both the AOT40 and SUM60 values were calculated for the four seasons of potato genotypes namely, April-July 2011 (Summer), January-April 2012 (Spring), April-July 2012 (Summer) and January-April 2013 (Spring) and compared with the critical limits set for potato crop. The growth and yield characteristics of potato genotypes were compared and evaluated under four different ambient ozone levels by the calculated exposure indices.

\section{(ii) IMPACT OF ELEVATED OZONE (O3) ON POTATO GENOTYPES}

An experiment was conducted under controlled open-top chamber condition to evaluate the impact of three elevated levels of ozone $\left(\mathrm{O}_{3}\right)\left(100,150\right.$ and $\left.200 \mathrm{ppb} @ 4 \mathrm{~h} \mathrm{~d}^{-1}\right)$ fumigated during the most important critical stage, tuber initiation stage of various genotypes of potato (Solanum tuberosum L.) on their physiological and yield characteristics. Moreover, the study is based on the fact that sudden exposure of ozone is more dangerous to crops than chronic long term exposure. The study aims to characterize the relative susceptibility / resistance of ten genotypes of potato (Kufri Surya, Kufri Swarna, Kufri Jyothi, Kufri Chipsona, Kufri Jawahar, Kufri Giriraj, Kufri Muthu, Kufri Himsona, Kufri Giridhari and Kufri Himalini). After exposure with elevated ozone levels @ 100,150 and 200 
ppb during the critical stage of crop (tuber initiation stage), the visible injury symptom of potato namely "speckle leaf" symptom were studied by the following visual scoring method (Burke et al. 2001). The fumigated potato plants were allowed to grow up to harvest and the yield parameters viz., the number of tubers plant ${ }^{-1}$ and tuber fresh weight plant $^{-1}$ were also calculated. A health set of potato plants were also maintained from planting to harvest for the purpose of comparison with performance of fumigated potato plants.

\section{RESULTS AND DISCUSSION}

The variation of $\mathrm{O}_{3}$ as a function of time is expressed as contour maps (Figure $1(\mathbf{a}) \boldsymbol{\&}(\mathbf{b})$ ) for the different potato growing seasons of summer 2011, spring and summer 2012 and spring 2013. The hourly mean $\mathrm{O}_{3}$ concentrations during January-April 2012 and 2013 (spring) were always $>40 \mathrm{ppb}$ and reached maximum up to 67 ppb whereas April-July 2011 and 2012 (summer) were between18-59 $\mathrm{ppb}$. The months of June and July recorded the lowest concentration of the hourly $\mathrm{O}_{3}$ values which is ranged between 18-38 ppb.

Taking over the advantage of usage of AOT40 and SUM60 values on crop effects, in assessing the impact of ambient $\mathrm{O}_{3}$ on the growth and yield characteristics of potato genotypes the cumulative values of AOT40 and SUM60 values were calculated for two seasons spring and summer (2011-2013) of potato crop. So, the calculated AOT40 value (Figure 2) during consecutive four seasons of potato April-July 2011 (Summer), January-April 2012 (Spring), April-July 2012 (Summer) and JanuaryApril 2013 (Spring) were observed to be 7059, 21,479, 5901 and 23,625 ppb h. These cumulative values can be compared with the critical levels of $5000 \mathrm{ppb}$ h (European Mapping Manual, 2010) for horticultural crops. The spring potato growing seasons of 2012 and 2013 showed manifold increase of values about 4.2 and 4.3 folds more than the critical level whereas the same method was used for assessment (Satsangi et al. 2004). The observed SUM60 values (Figure 3) for January-April 2012 and 2013 (spring) were found to be 25,800 ppbh and 29,483 ppbh which were much higher than the critical levels $(9,900-20,300 \mathrm{ppb})$ fixed for Norchip variety of potato (NAAQO 1999). The results showed that the occurrence of more of the ozone concentration values (Higher AOT40 values and SUM60 values) might caused their long- term exposure on potato which led reduction in plant height, above ground biomass and tuber yield (Table1). Reduction in the yield may result from ozone exposures decreases the carbon assimilation and translocation, nutrient acquisition and / or other physiological processes (Heath 1996).

The results of the controlled open-top chamber experiment with three elevated $\mathrm{O}_{3}$ levels (i.e., 100, 150 and $200 \mathrm{ppb}$ ) on ten potato genotypes showed that the number of tubers per plant was significantly the highest (6/ plant) at $100 \mathrm{ppb} \mathrm{O}_{3}$ for Kufri Surya, followed by Kufri Swarna, Kufri Jyothi (4 / plant), and for Kufri Chipsona, Kufri Jawahar, Kufri Giriraj (3 / plant) whereas the lower number of tubers ( 2 / plant) was recorded by Kufri Muthu, Kufri Himsona, Kufri Giridhari and Kufri Himalini as shown in table 2. At $150 \mathrm{ppb}$ level of $\mathrm{O}_{3}$, the number of tubers per plant was (4 / plant) for Kufri Surya, and Kufri Swarna, Kufri Jyothi, Kufri Chipsona showed 2 per plant whereas Kufri Jawahar, Kufri Giriraj and Kufri Muthu and Kufri Himsona showed a single tuber per plant and tubers were not formed for Kufri Giridhari and Kufri Himalini genotypes. At $200 \mathrm{ppb} \mathrm{O}_{3}$ fumigation, significantly the highest tubers formed in Kufri Surya ( 3 / plant) and the minimum number of tubers were formed i.e., ( 1 / plant) for Kufri Swarna, Kufri Jyothi, Kufri Chipsona and there was no tubers formation in other potato genotypes Kufri Jawahar, Kufri Giriraj, Kufri Muthu, Kuffri Himsona, Kufri Giridhari and Kufri Himalini. From the above results it was concluded that, the highest tuber formation was noticed in Kufri Surya at all three fumigation levels, whereas Kufri Giridhari and Kufri Himalini recorded significantly the lowest number of tuber per plant at $100 \mathrm{ppb}_{3}$ and no tuber formation was noticed at 150 and $200 \mathrm{ppb} \mathrm{O}_{3}$ levels. Moreover, majority of varieties did not show tuber formation at $200 \mathrm{ppb} \mathrm{O}_{3}$ (Table 2). Loss of photosynthetic capacity is an early effect of ozone exposure which is due to accelerated senescence with down-regulation of photosynthetic genes (McKee et al. 1997). Inhibition of $\mathrm{CO}_{2}$ assimilation can also result from direct or indirect inhibition of stomatal opening (Overmayer et al. 2008). Reductions in carbon acquisition are likely to result in a reduction of whole plant biomass, inducing yield reduction in crops by reducing the availability of leaf 
surface area to fix and provide carbon for reproductive parts which is stemming from reduced photosynthetic efficiencies and / or stomatal conductances (Betzelberger et al. 2010). Ozone induced reductions in yield of potato tubers is the direct consequence of ozone-induced reductions in photosynthesis and photosynthate allocation to the reproductive structures (Wilkinson et al. 2011).

\section{REFERENCES}

Anonymous. Ground- level ozone in the $21^{\text {st }}$ century: Future Trends, Impacts and Policy implications, Science Policy Report2008, 15/08 The Royal Society, London : 115.

Bell ML, Dominici F, Samet JM. A meta-analysis of time-series studies of ozone and mortality with comparison to the national morbidity, mortality, and air pollution study. Epidemiology 2005, $16(4), 436-45$

Betzelberger A, Gillespie MKM, McGrath JM. Effects of chronic elevated ozone concentration on antioxidant capacity, photosynthesis and seed yield of 10 soybean cultivars. Plant Cell and Environment 2010, 33, 1569-1581

Burke JI, Finnan JM, Donnelly A, Jones MB. The effects of elevated concentrations of carbon-dioxide and ozone on potato yield (Solanum tuberosum L) yield, Environmental Pollution 2001, 89 (3), 217-225.

Colls J. Air pollution an introduction. First edition E \& FN Spon 1997. London, 341.

Dentener F, Stevenson D, Cofala J, Mechler R, AmannM, Bergamaschi P, Raes F, Derwent R. The impact of air pollutant and methane emission controls on tropospheric $\mathrm{O}_{3}$ and radiative forcing: CTM calculations for the period 1990-2030. Atmospheric Chemistry and Physics 2005, 5, 1731-1755.

Emberson L, Büker P. Ozone: a threat to food security in South Asia: Policy Brief, 2008, Stockholm Environment Institute. http://www.sei.se.

FAO. 2000. Website of the FAO (http://www.fao.org)

Feng Z, Wang S, Szantoi Z, Chen S, Wang X. Protection of plants from ambient ozone by applications of ethylene diurea (EDU): a meta-analytic review. Environmental Pollution 2010, 158, 3236-3242..

Hagerman LM, Aneja VP, Lonneman WA. Characterization of non-methane hydrocarbons in the rural southeast United States. Atmospheric Environment 1997, 31, 4017-4038.

Heath RL. The modification of photosynthetic capacity induced by ozone exposure. In: Photosynthesis and the Environment, Advances in Photosynthesis 1996, 5 , 409-433.

Overmyer K, Kollist H, Tuominen H, Betz C. Complex phenotypic profiles leading to ozone sensitivity in Arabidopsis thaliana mutants. Plant, Cell and Environment 2008, 31, 1237 1249 .

IPCC. Atmospheric chemistry and greenhouse gases, In: Climate Change 2001: the Scientific Basis, Contribution of Working Group I. Third Assessment Report of the Intergovernmental Panel on Climate Change 2001, 239-287.

Ka"renlampi L, Ska"rby L. Critical levels for ozone in Europe: Testing and finalizing the concepts, UN-ECE Workshop Report 1996, 363, Department of Ecology and Environmental Science, University of Kuopio, Finland.

NAAQO. National Ambient Air Quality Objectives for Ground-Level Ozone - Summary Science Assessment Document1999, Cat. No. En 42-17/7-1-1999E.

NASA. News letter 2003, http://toms.gsfc.nasa.gov/news/news.html\#18-Nov.2003.

McKee IF, Bullimore JF, Long SP. Will elevated $\mathrm{CO}_{2}$ concentrations protect the yield of wheat from $\mathrm{O}_{3}$ damage. Plant, Cell and Environment 1997, 20, 77-84. 
Satsangi S, Lakhani C, Kulshrestha C, Taneja A. Seasonal Diurnal Variation of Surface Ozone and a Preliminary Anlysis of Exceedance of its Critical levels at a Semi-arid Site in India. Jr. Atmos Chem 2004, 47, 271-286.

Saurer M, Fuher J, Siegenthaler U. Influence of ozone on the stable carbon isotope composition, ${ }^{13} \mathrm{C}$ of leaves and grain of spring wheat (Triticum aestivum L.). Plant Physiol 1991, 97, 313-316.

Vingarzan RA. Review of surface ozone background levels and trends, Atmospheric Environment 2004, 38, 3431-3442.

Wilkinson S, Mills G, Illidge R. Temporal processes that contribute to nonlinearity in vegetation responses to ozone exposure and dose. Atmospheric Environment 2011, 43, 2919- 2928. 


\section{(Tables \& Figures)}

TABLE 1 Evaluation of potato genotypes based on their average tuber fresh weight, yield $\left(t \mathbf{~ h a ~}^{-1}\right)$ and yield reduction per cent during spring (Jan-Apr) and summer (Apr-July) seasons of the year 2011 to 2013

\begin{tabular}{|c|c|c|c|c|c|c|c|c|c|c|c|c|c|c|c|}
\hline \multirow{2}{*}{$\begin{array}{l}\text { Potato Genotypes } \\
\text { Seasons }\end{array}$} & \multicolumn{4}{|c|}{$\begin{array}{c}\text { Average Tuber fresh Weight } \\
\left(\mathrm{kg} \mathrm{plant}^{-1}\right)\end{array}$} & \multirow{2}{*}{$\begin{array}{l}1.1 .1 \\
\text { Mean }\end{array}$} & \multicolumn{2}{|r|}{1.1 .2} & \multicolumn{2}{|c|}{$\begin{array}{l}\text { Yield } \\
\left(\mathbf{t ~ h a}^{-1}\right)\end{array}$} & \multirow{2}{*}{$\begin{array}{l}1.1 .3 \\
\text { Mean }\end{array}$} & \multicolumn{4}{|c|}{1.1 .4} & \multirow{2}{*}{$\begin{array}{l}1.1 .5 \\
\text { Mean }\end{array}$} \\
\hline & $\mathbf{S}_{1}$ & $\mathbf{S}_{2}$ & $\mathbf{S}_{3}$ & $\mathbf{S}_{4}$ & & $\mathbf{S}_{1}$ & $\mathbf{S}_{\mathbf{2}}$ & $\mathbf{S}_{\mathbf{3}}$ & $\mathbf{S}_{4}$ & & $\mathbf{S}_{1}$ & $\mathbf{S}_{\mathbf{2}}$ & $\mathbf{S}_{\mathbf{3}}$ & $\mathbf{S}_{4}$ & \\
\hline Kufri Swarna & 1.25 & 0.49 & 5.65 & 0.47 & 1.96 & 23.58 & 22.28 & 23.86 & 22.26 & 22.99 & 5.65 & 10.85 & 4.56 & 10.95 & 8.00 \\
\hline Kufri Jyothi & 1.08 & 0.42 & 5.70 & 0.40 & 1.90 & 23.57 & 22.19 & 23.84 & 22.01 & 22.90 & 5.70 & 11.25 & 4.66 & 11.95 & 8.39 \\
\hline Kufri Giridhari & 0.95 & 0.65 & 7.25 & 0.62 & 2.36 & 23.19 & 20.02 & 23.26 & 19.66 & 21.53 & 7.25 & 19.90 & 6.98 & 21.35 & 13.87 \\
\hline Kufri Himalini & 0.92 & 0.58 & 7.45 & 0.56 & 2.37 & 23.13 & 19.69 & 23.24 & 18.63 & 21.17 & 7.45 & 21.25 & 7.05 & 25.50 & 15.31 \\
\hline \multirow[t]{2}{*}{ Mean } & 1.05 & 0.53 & 6.51 & 0.51 & & 23.36 & 21.04 & 23.55 & 23.14 & & 6.51 & 15.81 & 5.81 & 17.43 & \\
\hline & \multicolumn{2}{|c|}{ SEd } & \multicolumn{2}{|c|}{$\operatorname{CD}(0.05 \%)$} & & SEd & \multicolumn{3}{|c|}{ CD $(0.05 \%)$} & & \multicolumn{2}{|c|}{ SEd } & \multicolumn{2}{|c|}{ CD $(0.05 \%)$} & \\
\hline Genotypes & \multicolumn{2}{|c|}{0.05} & \multicolumn{2}{|c|}{0.10} & & 0.010 & \multicolumn{3}{|c|}{0.025} & & \multicolumn{2}{|c|}{0.010} & \multicolumn{2}{|c|}{0.020} & \\
\hline Seasons & \multicolumn{2}{|c|}{0.05} & \multicolumn{2}{|c|}{0.10} & & 0.010 & \multicolumn{3}{|c|}{0.025} & & \multicolumn{2}{|c|}{0.010} & \multicolumn{2}{|c|}{0.020} & \\
\hline$G \times S$ & \multicolumn{2}{|c|}{0.10} & \multicolumn{2}{|c|}{0.20} & & 0.020 & \multicolumn{3}{|c|}{0.050} & & \multicolumn{2}{|c|}{0.020} & \multicolumn{2}{|c|}{0.040} & \\
\hline
\end{tabular}

(Seasons- $\mathrm{S}_{1}$-April-July 2011, $\mathrm{S}_{2}$ - January-April 2012, $\mathrm{S}_{3}$-April-July 2012, S4- January - April 2013) 
TABLE 2 Impact of elevated ozone levels viz., 100, 150 and 200 ppb on the average no. of tubers plant during tuber initiation stage of potato genotypes

\begin{tabular}{|c|c|c|c|c|c|c|c|c|c|}
\hline $\begin{array}{c}\text { Potato } \\
\text { Genotypes }\end{array}$ & Treatments & $\begin{array}{l}\text { Average } \\
\text { No of } \\
\text { tubers } \\
\text { plant }^{-1}\end{array}$ & $\begin{array}{c}\text { Mean } \\
\text { values }\end{array}$ & $\begin{array}{c}\text { Per cent } \\
\text { difference } \\
\text { between } \\
\text { healthy } \\
\text { plant }\end{array}$ & $\begin{array}{c}\text { Potato } \\
\text { Genotypes }\end{array}$ & Treatments & $\begin{array}{c}\text { Average No } \\
\text { of tubers } \\
\text { plant }^{-1}\end{array}$ & $\begin{array}{l}\text { Mean } \\
\text { values }\end{array}$ & $\begin{array}{c}\text { Per cent } \\
\text { difference } \\
\text { between } \\
\text { healthy plant }\end{array}$ \\
\hline \multirow[t]{4}{*}{ Kufri Surya } & $\mathrm{T}_{1}$ & 6 & \multirow{3}{*}{4.33} & -25 & \multirow{4}{*}{ Kufri Giriraj } & $\mathrm{T}_{1}$ & 3 & \multirow{3}{*}{1.33} & -57.14 \\
\hline & $\mathrm{T}_{2}$ & 4 & & -50 & & $\mathrm{~T}_{2}$ & 1 & & -87.5 \\
\hline & $\mathrm{T}_{3}$ & 3 & & -62.5 & & $\mathrm{~T}_{3}$ & 0 & & -100 \\
\hline & $\mathrm{T}_{4}$ & 8 & & & & $\mathrm{~T}_{4}$ & 7 & & \\
\hline \multirow[t]{4}{*}{ Kufri Swarna } & $\mathrm{T}_{1}$ & 4 & \multirow{3}{*}{2.33} & -50 & \multirow{4}{*}{ Kufri Muthu } & $\mathrm{T}_{1}$ & 2 & \multirow{3}{*}{1.0} & -66.66 \\
\hline & $\mathrm{T}_{2}$ & 2 & & -75 & & $\mathrm{~T}_{2}$ & 1 & & -83.33 \\
\hline & $\mathrm{T}_{3}$ & 1 & & -87.5 & & $\mathrm{~T}_{3}$ & 0 & & -100 \\
\hline & $\mathrm{T}_{4}$ & 8 & & & & $\mathrm{~T}_{4}$ & 6 & & \\
\hline \multirow[t]{4}{*}{ Kufri Jyothi } & $\mathrm{T}_{1}$ & 4 & \multirow{4}{*}{2.33} & -50 & \multirow{4}{*}{ Kufri Himsona } & $\mathrm{T}_{1}$ & 2 & \multirow{3}{*}{1.0} & -66.66 \\
\hline & $\mathrm{T}_{2}$ & 2 & & -75 & & $\mathrm{~T}_{2}$ & 1 & & -83.33 \\
\hline & $\mathrm{T}_{3}$ & 1 & & -87.5 & & $\mathrm{~T}_{3}$ & 0 & & -100 \\
\hline & $\mathrm{T}_{4}$ & 8 & & & & $\mathrm{~T}_{4}$ & 6 & & \\
\hline \multirow[t]{4}{*}{ Kufri Chipsona } & $\mathrm{T}_{1}$ & 3 & \multirow{3}{*}{2.0} & -57.14 & \multirow{4}{*}{ Kufri Giridhari } & $\mathrm{T}_{1}$ & 2 & \multirow{3}{*}{0.66} & -75 \\
\hline & $\mathrm{T}_{2}$ & 2 & & -71.43 & & $\mathrm{~T}_{2}$ & 0 & & -100 \\
\hline & $\mathrm{T}_{3}$ & 1 & & -87.5 & & $\mathrm{~T}_{3}$ & 0 & & -100 \\
\hline & $\mathrm{T}_{4}$ & 7 & & & & $\mathrm{~T}_{4}$ & 8 & & \\
\hline \multirow[t]{4}{*}{ Kufri Jawahar } & $\mathrm{T}_{1}$ & 3 & \multirow{4}{*}{1.33} & -57.14 & \multirow{4}{*}{ Kufri Himalini } & $\mathrm{T}_{1}$ & 2 & \multirow{3}{*}{0.66} & -75 \\
\hline & $\mathrm{T}_{2}$ & 1 & & -87.5 & & $\mathrm{~T}_{2}$ & 0 & & -100 \\
\hline & $\mathrm{T}_{3}$ & 0 & & -100 & & $\mathrm{~T}_{3}$ & 0 & & -100 \\
\hline & $\mathrm{T}_{4}$ & 7 & & & & $\mathrm{~T}_{4}$ & 8 & & \\
\hline & & & & & & & SEd & $\begin{array}{c}\text { CD } \\
(0.05 \%)\end{array}$ & \\
\hline & & & & & Genotypes (G) & & 0.195 & 0.405 & \\
\hline & & & & & Treatments $(\mathrm{T})$ & & 0.231 & 0.264 & \\
\hline & & & & & $\mathrm{G} \times \mathrm{T}$ & & 0.426 & 0.669 & \\
\hline
\end{tabular}

$\left(\mathrm{T}_{1}-100 \mathrm{ppb} \mathrm{O}_{3} @ 4 \mathrm{hd}^{-1}, \mathrm{~T}_{2}-150 \mathrm{ppb} \mathrm{O}_{3} @ 4 \mathrm{~h} \mathrm{~d}^{-1}, \mathrm{~T}_{3}-200 \mathrm{ppb} \mathrm{O}_{3} @ 4 \mathrm{~h} \mathrm{~d}^{-1}, \mathrm{~T}_{4}-\right.$ Untreated). Mean values for $\mathrm{T}_{1}=3.1 \mathrm{~T}_{2}=1.4$ and $\mathrm{T}_{3}=0.6$. 


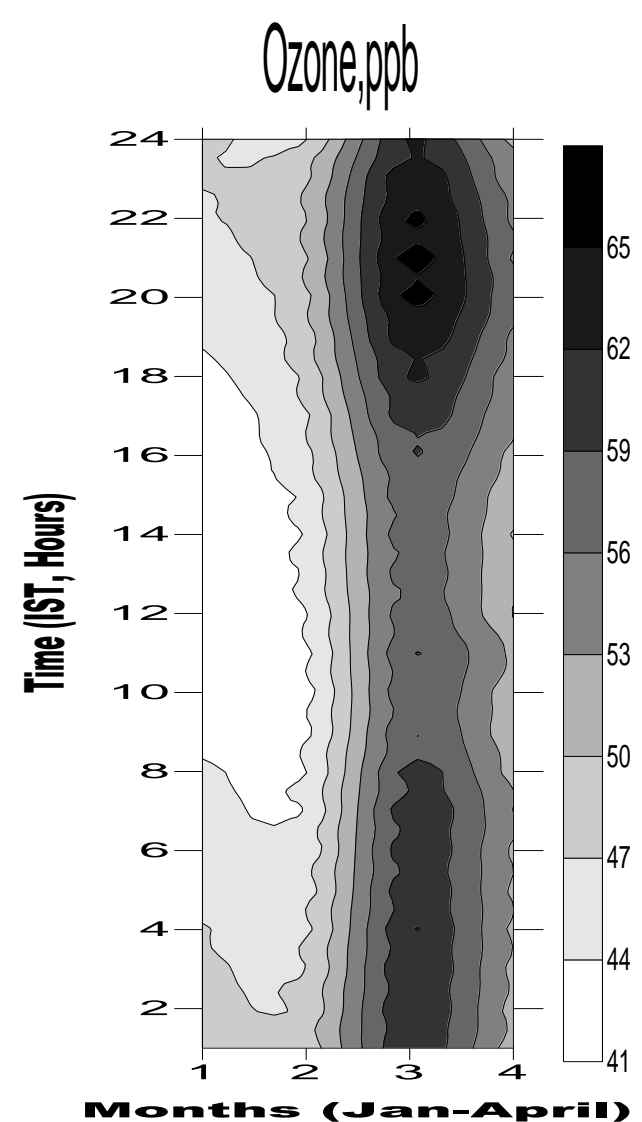

(a)

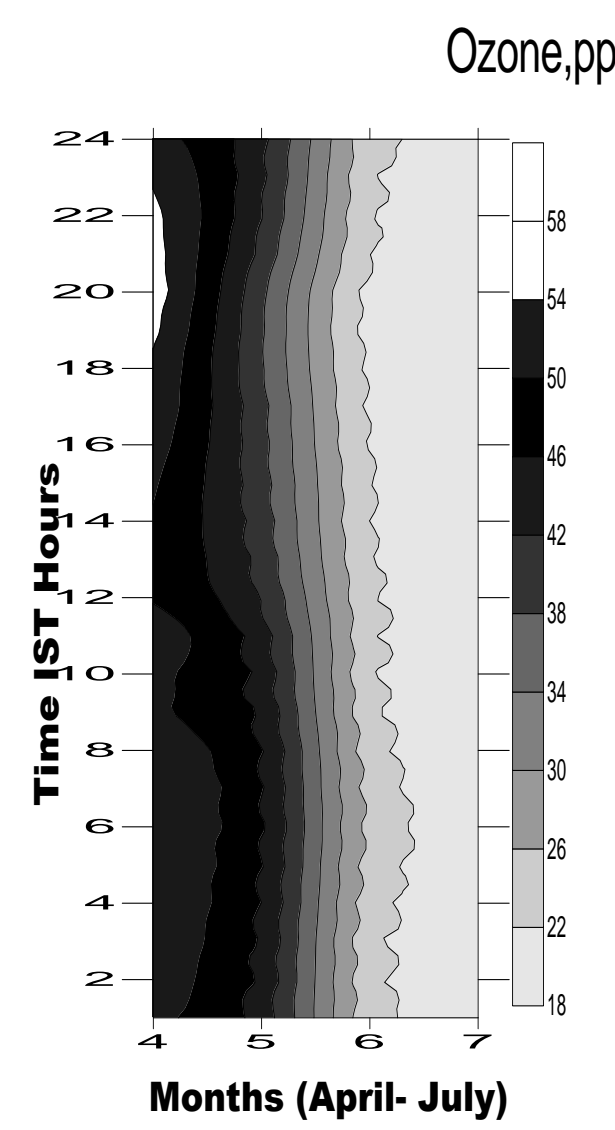

(b)

FIGURE 1(a). The hourly mean $\mathrm{O}_{3}$ concentrations during January -April (2012-2013) (average of two seasons of spring grown potato genotypes). 1 (b). Hourly mean $\mathrm{O}_{3}$ concentration during April-July (2011-2012) (average of two seasons of summer grown potato genotypes) 


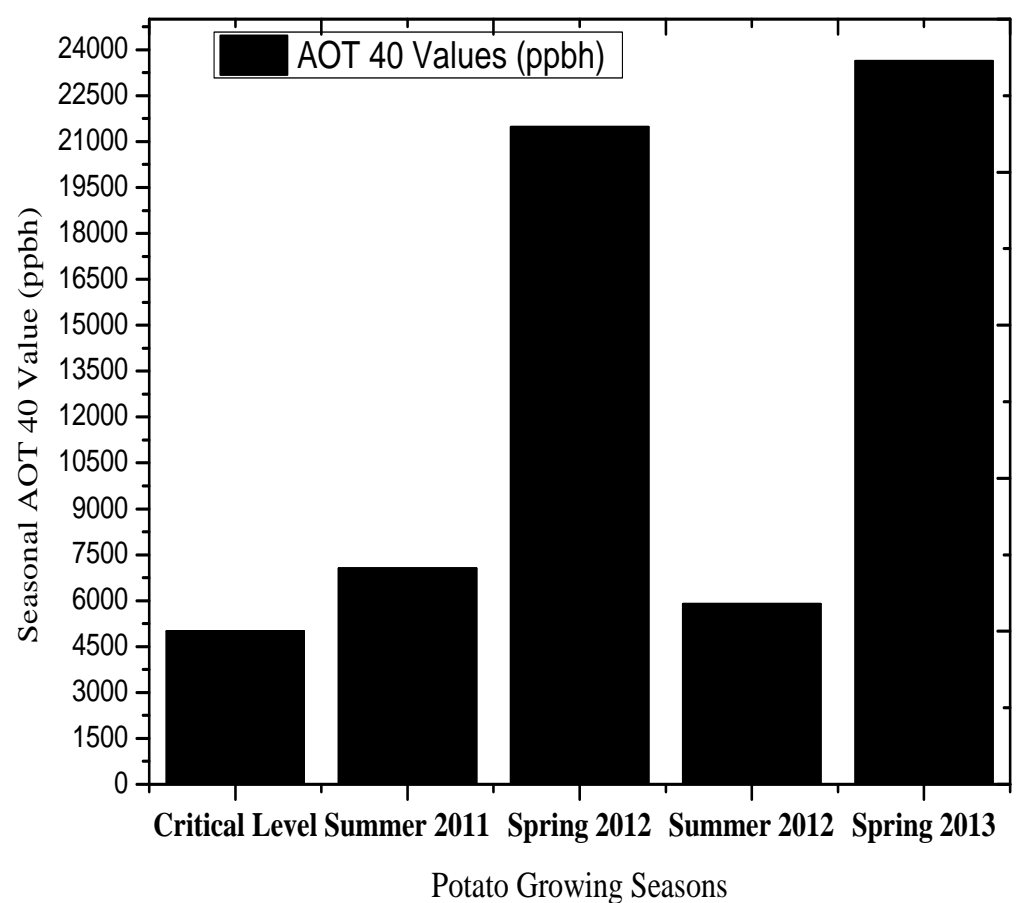

FIGURE 2.Calculated AOT40 values (ppbh) for four growing seasons of potato (2011-2013) 


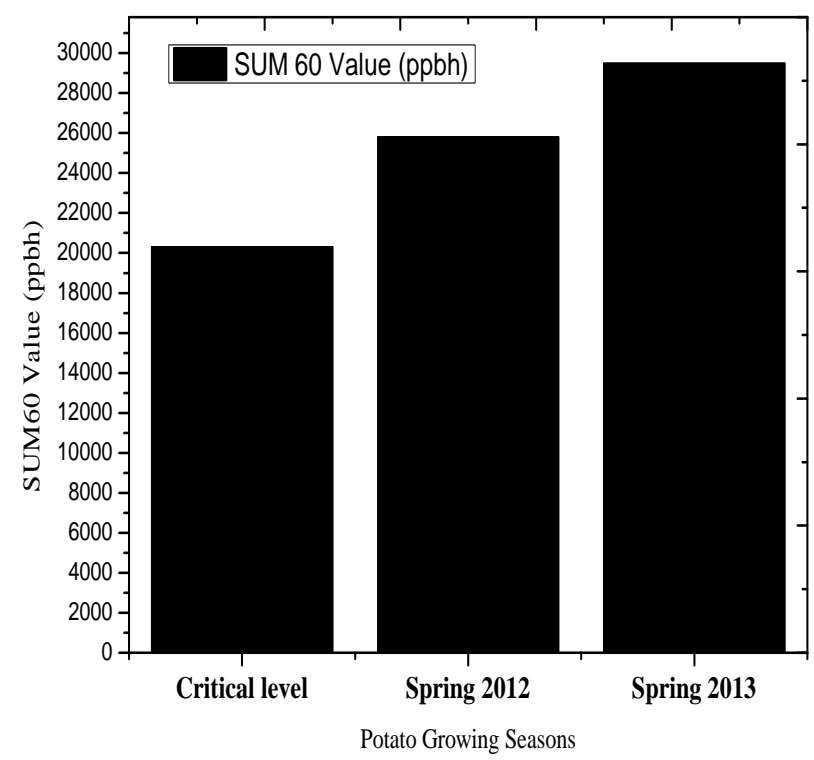

FIGURE 3. Calculated SUM 60 values (ppb h) during spring potato growing seasons (January to April) 2012-2013 